\title{
Morphometric Analysis of the Sacral Canal and Hiatus Using Multidetector Computed Tomography for Interventional Procedures
}

\author{
Girişimsel İşlemler İçin Sakral Kanal ve Hiatusun Çok Kesitli Bilgisayarlı \\ Tomografi ile Morfometrik Analizi
}

Alper KILICASLAN ${ }^{1}$, Fatih KESKIN ${ }^{2}$, Ozan BABAOGLU ${ }^{3}$, Funda GOK ${ }^{1}$, Mehmet Fatih ERDI ${ }^{2}$, Bulent $\mathrm{KAYA}^{2}$, Huseyin OZBINER 3 , Orhan OZBEK 3 , Osman $\mathrm{KOC}^{3}$, Burkay Kutluhan KACIRA ${ }^{4}$

${ }^{1}$ Necmettin Erbakan University, Meram Medical Faculty, Department of Anaesthesiology and Reanimation Konya, Turkey

${ }^{2}$ Necmettin Erbakan University, Meram Medical Faculty, Department of Neurosurgery, Konya, Turkey

${ }^{3}$ Necmettin Erbakan University, Meram Medical Faculty, Department of Radiology, Konya, Turkey

${ }^{4}$ Necmettin Erbakan University, Meram Medical Faculty, Department of Orthopaedic Surgery, Konya, Turkey

Corresponding Author: Alper KILICASLAN / E-mail: dralperkilicaslan@gmail.com

\begin{abstract}
AIM: The sacral canal has been frequently used as "a passage" for minimally invasive diagnostic and therapeutic procedures for spinal diseases. The aim of the present study was to investigate morphometric analyses of the sacral canal, hiatus, and surrounding structures according to different age groups and gender by using the "multidetector computed tomography" method.

MATERIAL and METHODS: Multiplanar-reconstructed images from 300 adult (150 females and 150 males, between 20 and 80 years old) were divided into three groups according to age and retrospectively examined. Various anatomic measurements of the sacral hiatus, surrounding structures, and sacral canal were performed. Sacral curvature angle and lumbosacral lordotic angle were noted.

RESULTS: Bony anatomic abnormalities such as absent hiatus (0.3\%), complete agenesis (1\%), and bony septum (2.6\%) were detected in some cases. The anteroposterior (AP) diameter of the hiatus was less than $2 \mathrm{~mm}$ in $5 \%$ of cases. In all groups, the mean values of the hiatus AP diameter and area, and the shortest distance of the sacral canal AP diameter were shorter in the 60-80 years age group when compared with those in 20-39 years age group ( $p=0.01$ ). The shortest sacral canal AP diameter was commonly located at the S2 and S3 levels in $59.2 \%$ and $33.9 \%$ of cases, respectively. The levels of maximum curvature were at S3 and S2 in $63.3 \%$ and $26.7 \%$ of cases, respectively. Median sacral curvature angles and lumbosacral lordotic angles were measured as $164^{\circ}$ and $134^{\circ}$, respectively.

CONCLUSION: Sacral structures have morphometric variations. Understanding of the detailed anatomy may improve the reliability of interventional procedures.
\end{abstract}

KEYWORDS: Sacral hiatus, Sacral canal, Multidetector computed tomography, Interventional procedures

Öz

AMAÇ: Yakın zamanda sakral kanal, omurga hastalıklarının minimal invaziv tanı ve tedavi işlemleri için "bir koridor olarak" sıkça kullanılmaya başlanmıştır. Çalışmanın amacı sakral kanalın, hiatusun ve çevre yapıların farklı yaş gurupları ve cinsiyete göre morfometrik analizlerinin çok kesitli bilgisayarlı tomografi yöntemiyle incelenmesidir.

YÖNTEM ve GEREÇLER: Üç farklı yaş grubuna (20-80 yaş arasında) ayrılan 300 yetişkin (150 kadın ve 150 erkek; 20-80 yaş) hastanın multiplanar rekonstrüksiyon görüntüleri kaydedildi ve geriye dönük olarak incelendi. Sakral hiatus ve çevre yapılar ile sakral kanala ait çeşitli anatomik ölçümler yapıldı. Sakral kurvatür açısı ve lumbosakral lordotik açı kaydedildi.

BULGULAR: Bazı olgularda hiatus yokluğu $(\% 0,3)$, komplet agenezis $(\% 1)$ ve kemik septum $(\% 2,6)$ gibi kemik anomalilerine rastlandı. Anteroposterior (AP) Hiatus çapı olguların \%5'sinde $2 \mathrm{~mm}$ nin altındaydı. Tüm yaş gruplarında, hiatus AP çapı ve hiatus alan ve "sakral kanal AP çapının en kısa mesafesinin" ortalaması, 60-80 yaş grubunda, 20-40 yaş grubuna göre daha kısaydı ( $p=0,01)$. Sakral kanal AP çapın en küçük olduğu lokalizasyon, en çok olguların \%59,2'unda S2 ve \%33,9'unda S3 seviyesinde idi. Maksimum kurvatür seviyesi olguların \%63,3'ün de S3 ve \%26,7'sin de S2 seviyesinde idi. Sakral kürvatur açı ve lumbosakral lordotik açı sırayla $164^{\circ}$ and $134^{\circ}$ olarak ölçüldü.

SONUÇ: Sakral yapılarda anatomik varyasyonlar sık görünür. Anatominin ayrıntılı analizi, girişimsel işlemlerin başarısını ve güvenilirliğini artırabilir.

ANAHTAR SÖZCÜKLER: Sakral hiatus, Sakral kanal, Çok kesitli bilgisayarlı tomografi, Girişimsel işlemler 


\section{INTRODUCTION}

The sacral hiatus originates from a fusion defect of the fifth sacral vertebral lamina at the end of the sacral canal. The approach to the epidural area via the sacral hiatus (caudal) is used for anesthesia and analgesia during many operations by anesthesiologists (6). Moreover, "caudal epidural drug applications" are used to treat, in particular, chronic back pain and other spinal disorders by clinicians from different specialties $(5,7)$.

Parallel to the development of fiberoptic imaging methods, the sacral canal is used more frequently as "a passage" for minimally invasive diagnostic and therapeutic procedures (i.e. epiduroscopy) of vertebral/spinal diseases $(3,10,13)$. It has been reported that the sacral approach could be used among procedures performed in the spinal area, such as percutaneous intraspinal navigation (PIN) (12).

For successive performances of all these interventions, first, the sacral hiatus should be located, and then the equipment to be used should be advanced along the canal. However, depending on the wide anatomic variations of this area, these procedures may be difficult to perform or not performed at all $(1,19)$. Moreover, anatomy of this area shows variability according to race (2). Therefore, detailed anatomic measurements and the variations of the sacral hiatus, canal, and surrounding structures must be thoroughly understood in order to perform successful procedures. A majority of previous morphometric studies related to sacral canal structures were conducted using post-mortem "dry sacral bones" $(11,16,17)$. However, limitations including the nonevaluation of structures other than bones, and undefined age and gender are present. In addition, although the anatomy of sacral hiatus and structures in the outer sections were not reported in detail, information related to the sacral canal was limited. Multidetector computed tomography (MDCT) is the preferred imaging method for the evaluation of pelvicvertebral musculoskeletal structures $(4,9)$. According to our knowledge, information related to detailed morphometric analysis of this area is inadequate.

The aim of the present study was to investigate the morphometric analyses of the sacral canal, hiatus, and surrounding structures according to different age groups and gender by using the MDCT method.

\section{MATERIAL and METHODS}

This study was approved by the Institutional Ethical Committee and the study was performed in accordance with the ethical principles for human investigations, as outlined by the Second Declaration of Helsinki.

\section{Cases}

A random list of 300 (aged 20-80 years) recent abdominopelvic MDCT images were reviewed retrospectively. Age, gender and height were obtained from patient records. To determine aging-related anatomical changes and intergender differences, the patients were divided into 3 different age groups with equal number of female and male patients. Patients aged between 20 and 39 years were defined as young, between 40 and 59 years as middle-aged, and between 60 and 80 years were defined as old.

The analysis was performed in three parts.

\section{Part 1: Metric analysis}

The acquisition and reconstruction parameters were defined as follows: $1.2 \mathrm{~mm}$ collimation, tube voltage of $120 \mathrm{KVp}$, tube current of $160 \mathrm{mAs}$, reconstruction interval of $0.625 \mathrm{~mm}$, reconstruction thickness $1.5 \mathrm{~mm}$, gantry rotation speed of 0.5 second and pitch of $1 \mathrm{~mm}$. Complete abdominal scanning was performed between the diaphragm and the greater trochanter. All parameters were measured in the Leonardo Workstation (Siemens Healthcare Germany) imaging procedure unit by two radiology specialists experienced in vertebral radiology, and a statistical analysis of those measurements was performed. Multiplanar reconstruction (MPR) for the mid-sagittal plane and maximum intensity projection (MIP) reformat images for bicornal measurements were used in sacral canal metric analyses. The data were then re-analyzed according to gender and age groups. Cases with absent hiatus and complete agenesis were not included in the metric analysis.

The following parameters described in Figure $1 A, B ; 2 A, B$ and $3 A, B$ were measured:

1. Anteroposterior (AP) diameter of the sacral canal at the apex of the hiatus (Figure $1 \mathrm{~A}$ )

2. Shortest AP diameter of the sacral canal at the midline (Figure1A)

3. Distance from the sacral curvature to the hiatus (Figure 1B)

4. Length of the sacral canal (Figure 1B)

5. Transverse (TR) diameter of the sacral canal at the apex of the hiatus (Figure 2A)

6. Sacral hiatus space (at the apex of the hiatus) (Figure 2B)

7. Distance between inner surfaces of bilateral sacral cornu (Figure 3A)

8. Length of the sacral hiatus (Figure 3B)

\section{Part 2: Angulation analysis}

Sagittal reconstruction images were used for angle measurements. In the midline sagittal image, a line was drawn from the sacral hiatus to the posterior wall of the sacral canal (until the vertebral segment at the first angulation). After this point, the second straight line continued to the anterior wall, just below the interlaminar line. The third line was elongated across three vertebra segments in the cranial direction (7). Respective kyphotic and lordotic angles, which occurred on this line, were measured (Figure 4A, B). Mean values of measurements were calculated, and then data were re-analyzed according to gender and age groups. 
The following parameters described in Figure $4 A, B$ were measured:

1. Sacral curvature angle (Figure $4 \mathrm{~A}$ )

2. Lumbosacral lordotic angle (Figure 4B)

\section{Part 3: Non-metric analysis}

1. Defect in dorsal wall of sacrum

2. Presence of bony septum

3. Definition of Sacral Cornu: Absence or presence of sacral cornu and short sacral cornu (sacral cornu of less than 3 $\mathrm{mm}$ was considered short)
4. Location of the maximum curvature of the sacrum

5. Location of the shortest AP diameter of the sacral canal at the midline

\section{Statistical analysis}

Our sample size calculation is based on the definition of differences between the AP diameter of sacral hiatus measurements as the primary outcome. After obtaining the AP diameter of sacral hiatus of the first thirty patients in different age groups in the study and assuming a two-tailed a value of 0.05 (sensitivity $95 \%$ ) and a $\beta$ value 0.20 (study power: $80 \%)$, we determined that at least 45 patients were required in each age group and we decided to enroll 50 patients in

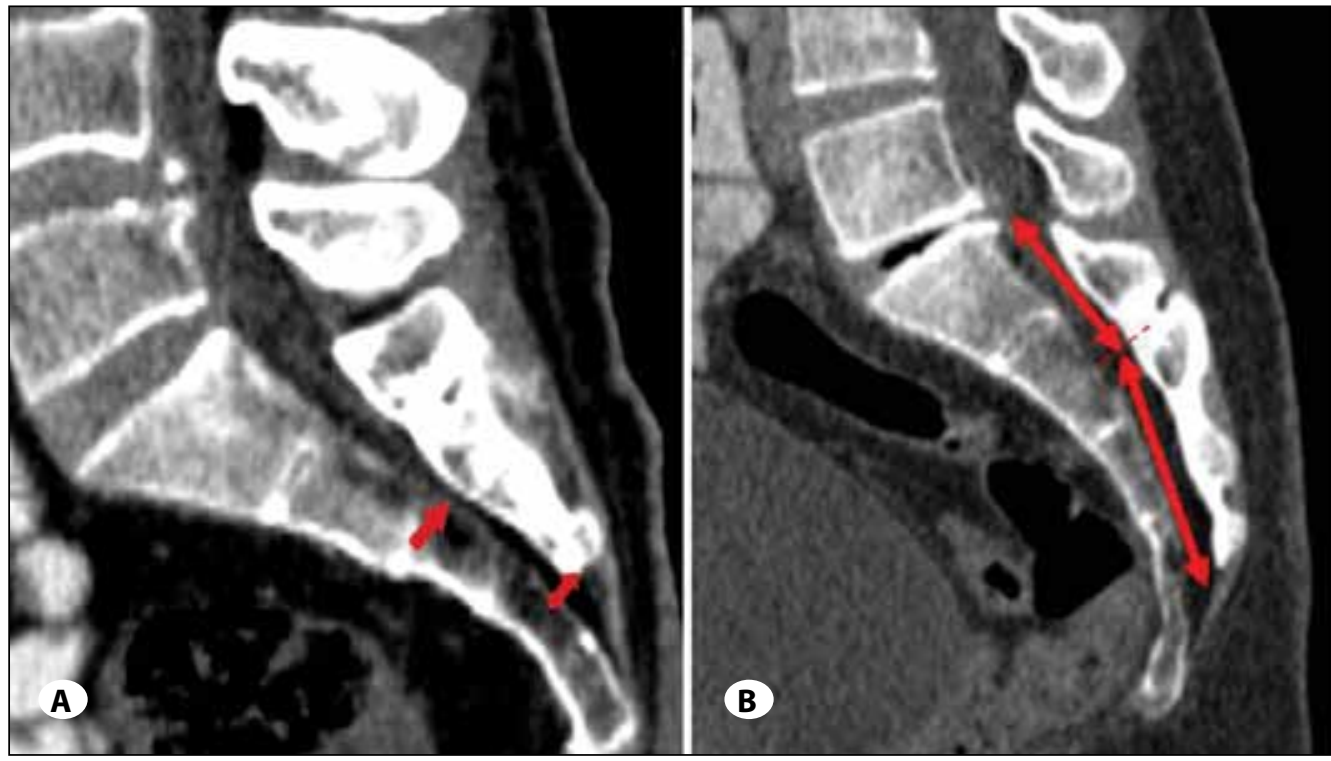

Figure 1: Sagittal CT reconstruction of the sacral canal. A) AP diameter at the apex of the hiatus; (bottom arrow); Shortest AP diameter of sacral canal at midline (top arrow) B) Distance between curvature and hiatus (bottom arrow); length of sacral canal (top and bottom arrow)
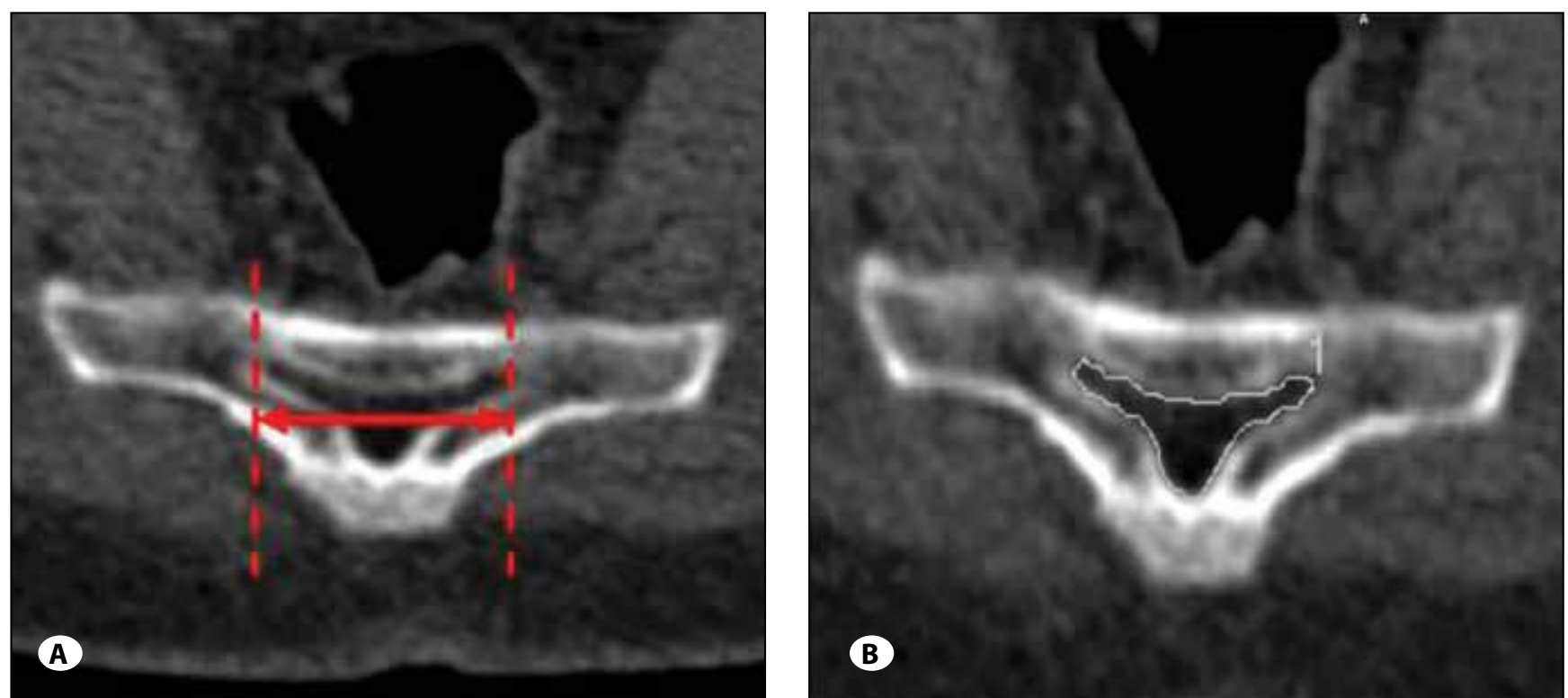

Figure 2: Transverse CT reconstruction showing the; A) TR diameter of the sacral canal at the apex of the hiatus (arrow), B) manual tracing of the area of the sacral canal. 
each age group (G Power 3 power analysis programme) (8). Statistical analysis was performed using the Statistical Package for Social Sciences version 16.0 for Windows (SPSS Inc, Chicago, IL, USA). Normal distribution was tested with the Kolmogorov-Smirnov test. Comparison according to gender was performed by using independent sample t-test. One way ANOVA variance analysis was used to compare age groups within themselves. Post-hoc evaluation was performed by

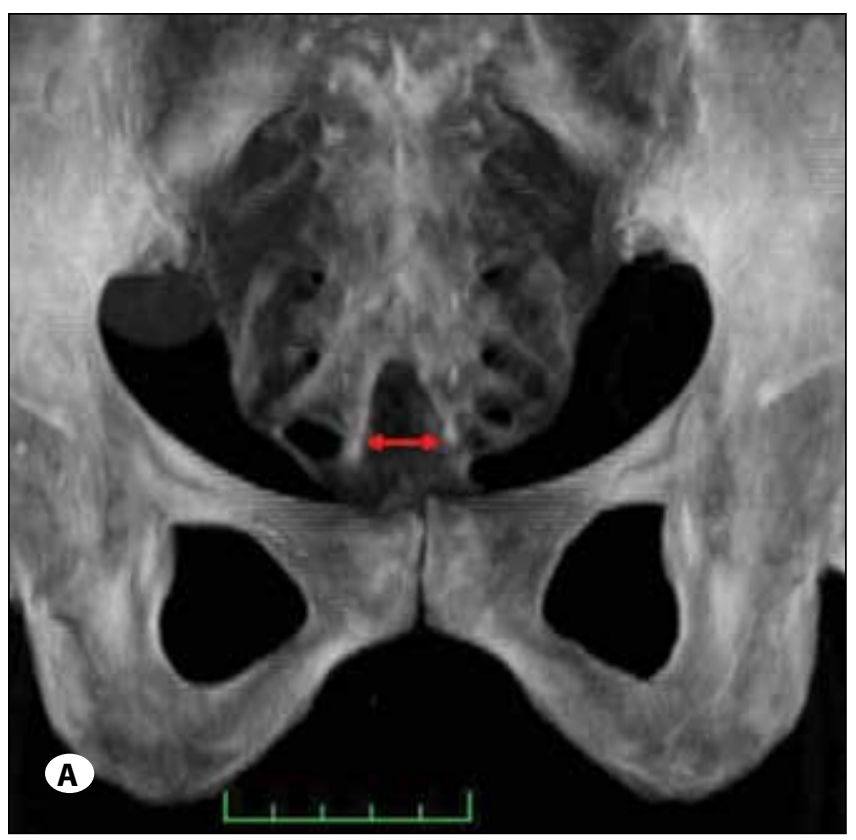

using Tukey's HSD. The data are expressed as mean with standard deviation (SD) for normally distributed variables or as median with interquartile range (IQR) for non-normally distributed variables and presented both for gender and age groups. The level of significance was accepted as $P<0.05$.

\section{RESULTS}

Fifty female and 50 male cases were analysed in each of the

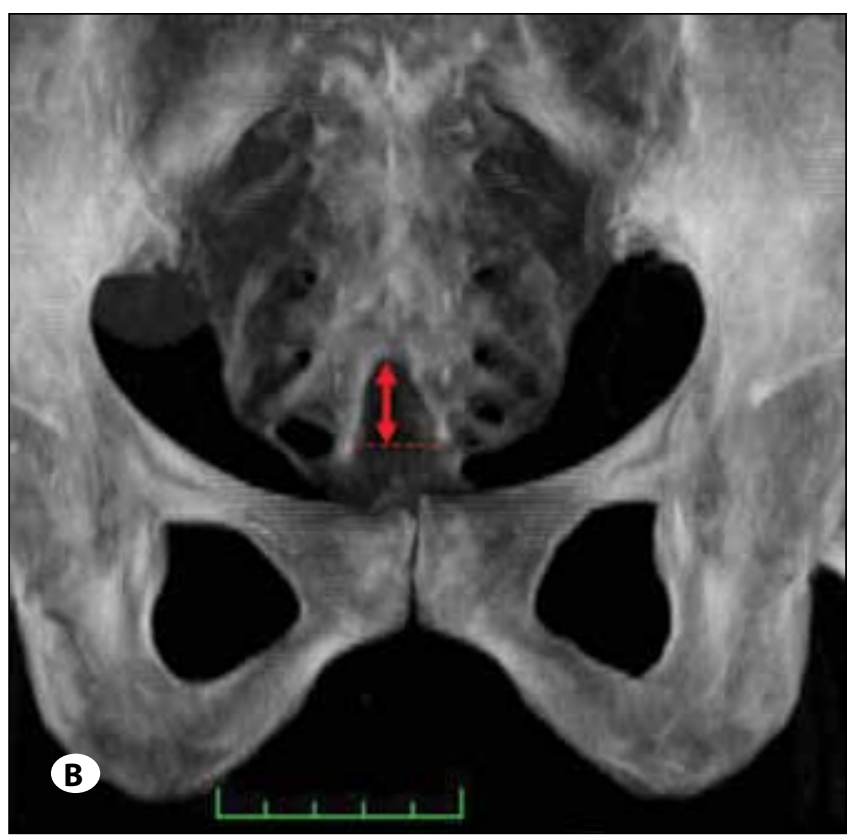

Figure 3: Three dimensional CT reconstruction of the sacrum showing A) the distance between bilateral cornua (arrow), B) the length of sacral hiatus (arrow).
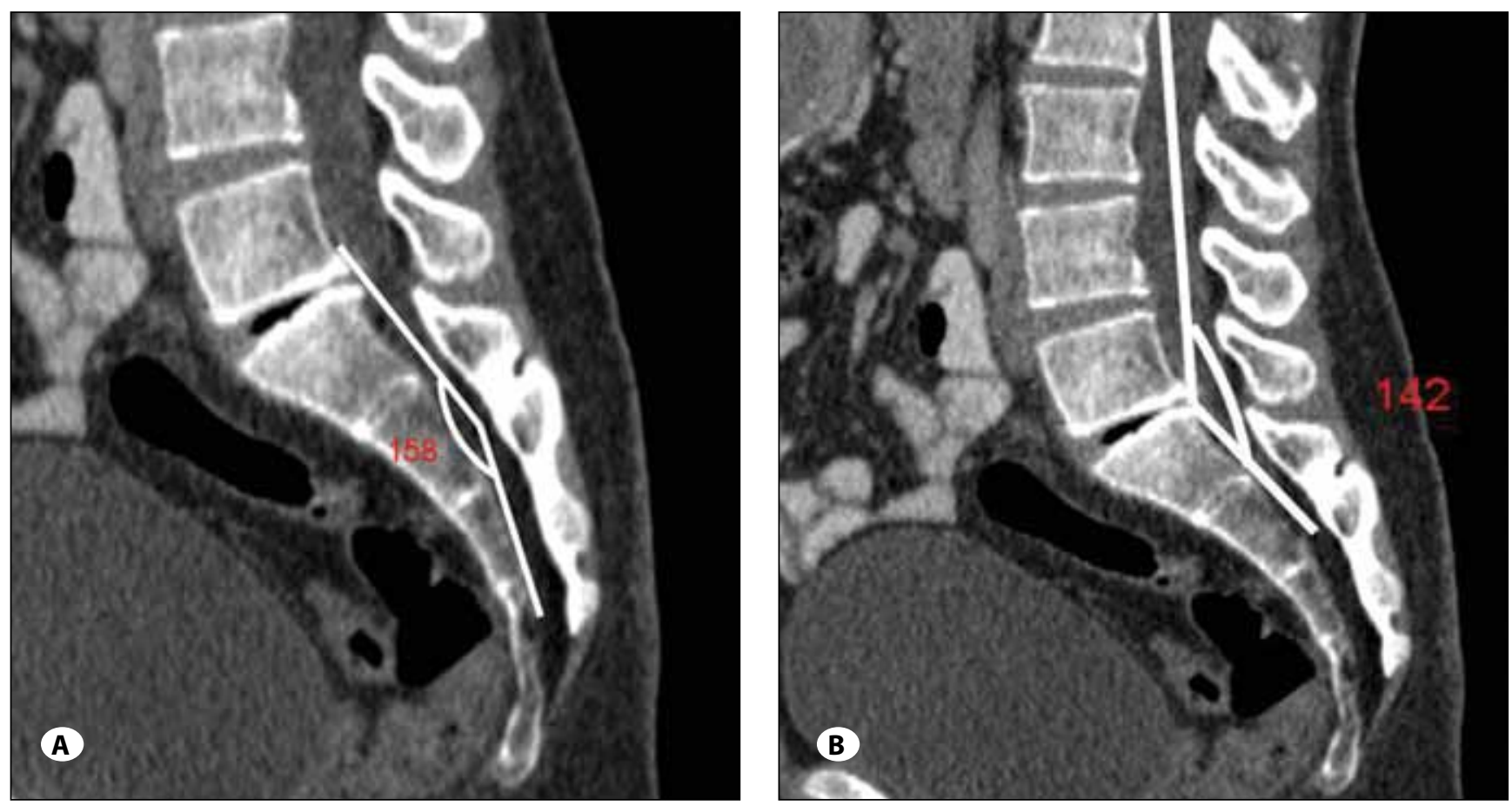

Figure 4: Sagittal CT reconstruction of the sacral canal showing the ; A) sacral curvature angle B) lumbosacral lordotic angle. 
three age groups. Four cases that were detected to have absent hiatus and complete agenesis were not included in the metric evaluation.

\section{Part 1: Metric analysis}

Three male patients (aged 28, 30, and 66 years) who had absence of the posterior sacrum wall (complete agenesis) were excluded from metric measurements. In addition, the hiatus measurements of a 75-year-old male patient with hiatal agenesis could not be performed. Mean values and standard deviations of measured parameters were calculated. Results are given in Tables I, II, and III.

The AP diameter of hiatus was below $1 \mathrm{~mm}$ in $0.3 \%$ of cases; below $2 \mathrm{~mm}$ in $5 \%$ of cases; below $2.5 \mathrm{~mm}$ of $12.7 \%$ of cases; and below $3 \mathrm{~mm}$ in $19.3 \%$ of cases. When data were evaluated

Table I: Results of the Anatomical Measurements of Sacral Hiatus (SH) and Sacral Cornua (SC). Data are Presented as Mean \pm SD

\begin{tabular}{|c|c|c|c|c|c|c|}
\hline Gender & $\begin{array}{c}\text { Age (year) and } \\
\text { Number of the } \\
\text { Patients }\end{array}$ & $\begin{array}{l}\text { AP diameter of } \\
\text { SH (mm) }\end{array}$ & $\begin{array}{c}\text { Transverse } \\
\text { Diameter of SH } \\
(\mathrm{mm})\end{array}$ & SH Area $\left(\mathrm{cm}^{2}\right)$ & $\begin{array}{c}\text { Length of the SH } \\
(\mathrm{mm})\end{array}$ & $\begin{array}{l}\text { Distance Between } \\
\text { Bilateral Cornua } \\
\text { (mm) }\end{array}$ \\
\hline \multirow{3}{*}{ M } & $\begin{array}{c}20-39 \\
n: 48\end{array}$ & $4.3 \pm 1.1$ & $21 \pm 4.4$ & $1.2 \pm 0.4$ & $23.1 \pm 8.7$ & $10.4 \pm 3.1$ \\
\hline & $\begin{array}{c}40-59 \\
n: 50\end{array}$ & $4.1 \pm 1.6$ & $21.1 \pm 3.5$ & $1 \pm 0.8$ & $22.5 \pm 8.2$ & $11.4 \pm 3.2$ \\
\hline & $\begin{array}{c}60-80 \\
n: 48\end{array}$ & $3.9 \pm 1.2$ & $20.5 \pm 5.1$ & $0.9 \pm 0.2$ & $22.2 \pm 9.2$ & $10.8 \pm 3.4$ \\
\hline \multirow{3}{*}{$F$} & $\begin{array}{c}20-39 \\
n: 50\end{array}$ & $4.4 \pm 1.2$ & $21.2 \pm 4.1$ & $1.3 \pm 0.4$ & $22.1 \pm 8.5$ & $10.4 \pm 2.6$ \\
\hline & $\begin{array}{c}40-59 \\
n: 50\end{array}$ & $4.1 \pm 1.1$ & $19.8 \pm 3.5$ & $0.9 \pm 0.2$ & $21.6 \pm 9.2$ & $10.5 \pm 3$ \\
\hline & $\begin{array}{c}60-80 \\
n: 50\end{array}$ & $3.9 \pm 1.2$ & $20.2 \pm 3.3$ & $0.89 \pm 0.2$ & $21.1 \pm 8.9$ & $11.5 \pm 2.9$ \\
\hline \multicolumn{2}{|c|}{ Combined n:296 } & $\begin{array}{r}4.1 \pm 1.3 \\
(0.7-9.8)\end{array}$ & $\begin{array}{c}20.9 \pm 3.8 \\
(11.9-33.9)\end{array}$ & $\begin{array}{c}1 \pm 0.3 \\
(0.35-1.9)\end{array}$ & $\begin{array}{l}22.1 \pm 9.2 \\
(4.5-42)\end{array}$ & $\begin{array}{c}10.7 \pm 3.1 \\
(7-19)\end{array}$ \\
\hline
\end{tabular}

$\mathbf{M}=$ Male, $\mathbf{F}=$ Female.

Table II: Results of the Anatomical Measurements of Sacral Canal. Data are Presented as Median (IQR) or mean \pm SD.

\begin{tabular}{|c|c|c|c|c|c|c|}
\hline Gender & $\begin{array}{c}\text { Age (year) and } \\
\text { Number of the } \\
\text { Patients }\end{array}$ & $\begin{array}{c}\text { Sacral } \\
\text { Curvature Angle } \\
\text { (median,IQR) }\end{array}$ & $\begin{array}{l}\text { Lumbosacral } \\
\text { Lordotic Angle } \\
\text { (median, IQR) }\end{array}$ & $\begin{array}{c}\text { Distance from } \\
\text { Sacral Curvature } \\
\text { to Hiatus (mm) }\end{array}$ & $\begin{array}{l}\text { Length of Sacral } \\
\text { Canal (mm) }\end{array}$ & $\begin{array}{c}\text { Shortest AP } \\
\text { Diameter of Sacral } \\
\text { Canal }(\mathrm{mm})\end{array}$ \\
\hline \multirow{3}{*}{$M$} & $\begin{array}{c}20-39 \\
n: 48\end{array}$ & $\begin{array}{c}164^{\circ} \\
{\left[160^{\circ}-167^{\circ}\right]}\end{array}$ & $\begin{array}{c}137^{\circ} \\
{\left[131.5^{\circ}-141.5^{\circ}\right]}\end{array}$ & $39.6 \pm 14.5$ & $90.8 \pm 15.2$ & $3.8 \pm 1$ \\
\hline & $\begin{array}{c}40-59 \\
n: 50\end{array}$ & $\begin{array}{c}165^{\circ} \\
{\left[159^{\circ}-169^{\circ}\right]}\end{array}$ & $\begin{array}{c}136^{\circ} \\
{\left[131^{\circ}-143^{\circ}\right]}\end{array}$ & $43.6 \pm 18.5$ & $88.1 \pm 14.1$ & $3.6 \pm 0.9$ \\
\hline & $\begin{array}{c}60-80 \\
n: 48\end{array}$ & $\begin{array}{c}164^{\circ} \\
{\left[160^{\circ}-168^{\circ}\right]}\end{array}$ & $\begin{array}{c}137^{\circ} \\
{\left[130^{\circ}-140^{\circ}\right]}\end{array}$ & $44.5 \pm 15.8$ & $88.4 \pm 14.4$ & $3.4 \pm 3$ \\
\hline \multirow{3}{*}{$F$} & $\begin{array}{c}20-39 \\
n: 50\end{array}$ & $\begin{array}{c}166^{\circ} \\
{\left[162^{\circ}-170^{\circ}\right]}\end{array}$ & $\begin{array}{c}133^{\circ} \\
{\left[128^{\circ}-139^{\circ}\right]}\end{array}$ & $36.6 \pm 14.8$ & $84.7 \pm 15.7$ & $3.9 \pm 1$ \\
\hline & $\begin{array}{c}40-59 \\
n: 50\end{array}$ & $\begin{array}{c}165^{\circ} \\
{\left[159^{\circ}-168^{\circ}\right]}\end{array}$ & $\begin{array}{c}132^{\circ} \\
{\left[130^{\circ}-140^{\circ}\right]}\end{array}$ & $38.7 \pm 16.9$ & $83.5 \pm 14.9$ & $3.8 \pm 0.7$ \\
\hline & $\begin{array}{c}60-80 \\
n: 50\end{array}$ & $\begin{array}{c}164^{\circ} \\
{\left[160^{\circ}-167^{\circ}\right]}\end{array}$ & $\begin{array}{c}132^{\circ} \\
{\left[127^{\circ}-138^{\circ}\right]}\end{array}$ & $38.5 \pm 16.3$ & $81.4 \pm 13.4$ & $3.5 \pm 1$ \\
\hline \multicolumn{2}{|c|}{ Combined n:296 } & $\begin{array}{c}164^{\circ} \\
{\left[160^{\circ}-168^{\circ}\right]}\end{array}$ & $\begin{array}{c}134^{\circ} \\
{\left[130^{\circ}-140^{\circ}\right]}\end{array}$ & $\begin{array}{c}39.5 \pm 16.5 \\
(14.3-73.4)\end{array}$ & $\begin{array}{l}85.5 \pm 14 \\
(36-119)\end{array}$ & $\begin{array}{c}3.7 \pm 1 \\
(1-6)\end{array}$ \\
\hline
\end{tabular}


Table III: Location of Maximum Curvature of Sacrum and Shortest Anteroposterior (AP) Diameter of Sacral Canal. Data are Presented as Numbers and Percentages

\begin{tabular}{|c|c|c|c|c|}
\hline \multirow[b]{2}{*}{ Gender } & \multicolumn{2}{|c|}{$\begin{array}{l}\text { Location of maximum curvature of sacral } \\
\qquad \text { canal (\%) }\end{array}$} & \multicolumn{2}{|c|}{$\begin{array}{l}\text { Location of shortest AP diameter of sacral } \\
\qquad \text { canal (\%) }\end{array}$} \\
\hline & $M$ & $\mathrm{~F}$ & $M$ & $\mathrm{~F}$ \\
\hline S1 & - & - & $1(0.55)$ & $1(0.55)$ \\
\hline $\mathrm{S} 2$ & $40(13.5)$ & 40 (13.5) & $53(31.4)$ & $50(27.8)$ \\
\hline S3 & 94 ( 31.6$)$ & 93 (31.3) & 34 (19.5) & 25 (14.4) \\
\hline S4 & $13(4.3)$ & $17(5.7)$ & $5(2.9)$ & $5(2.9)$ \\
\hline
\end{tabular}

$\mathbf{M}=$ Male, $\mathbf{F}=$ Female .

without gender differentiation, the AP diameter of hiatus in both females and males was shorter in the $60-80$ years age group than in the 20-39 years age group $(p=0.01)$ (Table I). The hiatus area was shorter in the $60-80$ years age group compared to the $20-39$ years age group $(p=0.006)$ (Table I).

Anterio-posterior diameter decreased at a specific area at the midline of the sacral canal in $59.2 \%$ of cases. The shortest diameter of sacral canal was below $2 \mathrm{~mm}$ in $4.8 \%$ of cases; below $2.5 \mathrm{~mm}$ of $14.7 \%$ of cases; and below $3 \mathrm{~mm}$ in $24 \%$ of cases, while it was above $1 \mathrm{~mm}$ in all cases. There was no difference between males and females $(p=0.1)$; it was shorter in the 60-80 years age group compared to the $20-39$ years age group ( $\mathrm{p}=0.01$ ) (Table II). The shortest diameter was located at the S2 and S3 levels in $59.2 \%$ and $33.9 \%$ of cases, respectively (Table III). The mean value of the shortest distance of the sacral canal AP diameter was shorter than that of the AP diameter of the sacral hiatus $(p=0.01)$ in $59.2 \%$ of cases. No statistically significant difference was detected in the age groups among the other measured parameters.

The mean body height of the male subjects $[(171.6 \pm 6.4$ $\mathrm{cm}$ ) (range 162-188cm)] was statistically longer compared to female subjects $[(162.5 \pm 5.5 \mathrm{~cm})$ (range 150-172 cm)] $(p=0.001)$ and the sacral canal distance was longer in males than females $(p=0.004)$ (Table II), and sacral curvature-hiatus distance was longer in males than the females $(p=0.01)$ (Table II).

\section{Part 2: Angulation analysis}

Sacral curvature and lumbosacral lordotic angles are presented as median and interquartile (lower quartile-upper quartile) range (Table II). When the sacral curvature angle and the lumbosacral lordotic angle values were evaluated, there was no significant difference between the age groups. When the differences between females and males were compared, the lumbosacral lordotic angle was greater in males than in females $(p=0.002)$

\section{Part 3: Non-metric analysis}

1. Defect in the dorsal wall of sacral canal:

Complete agenesis (spina bifida) due to the absence of the posterior sacrum wall was detected in three cases (1\%); fusion deficiency of the neighboring laminae was detected in five cases (1.6\%), and thus, partial agenesis was observed.

\section{Presence of bony septum}

Bony septum was present in a total of 31 (10.03\%) cases. Bony septa were located in the middle of the sacral canal in eight cases (2.6\%); on the left side in 10 cases (3.3\%); on the right side in 14 cases $(4.4 \%)$.

\section{Definition of sacral cornu:}

Among the cases in the current study, there were bilateral plane cornu in $3 \%$ of cases, unilateral plane cornu in $5 \%$ of cases, bilateral short cornu in $7 \%$ of cases, and unilateral short cornu in $15.3 \%$ of cases.

\section{Location of the maximum curvature of the sacrum}

Distributions of sacral angulations according to segments are presented in Table III. The most common angulations were observed at the $\mathrm{S} 3$ level in $63.3 \%$ of cases.

5. Location of the shortest AP diameter of the sacral canal at the midline

Anterio-posterior diameter decreased at a specific area at the midline of the sacral canal in $59.2 \%$ of cases. Levels of the shortest AP diameter of the sacral canal are presented in Table III.

\section{DISCUSSION}

Although the sacral canal has a high rate of anatomic variations, it is a useful approach for diagnosis and treatment of spinal diseases, because it has suitable morphometric parameters. In the present study, detailed morphometric analyses of sacral hiatus, sacral canal, and surrounding structures were evaluated according to both age and gender using the MDCT method. For successful interventions, sacral hiatus should be identified first. The equipment should then be inserted in the hiatus, and progressed along the sacral canal. The sacral hiatus is covered by only the sacrococcygeal membrane, subcutaneous adipose tissue, and skin is commonly used for CEB.

The sagittal AP diameter at the hiatus apex is the narrowest part of the hiatus and it is one of the most important parameters to define the dimensions of the equipment. The mean AP diameter was defined as $4.1 \pm 1.3 \mathrm{~mm}$ in the current study. Senoglu et al. reported this diameter as $4.46 \pm 1.3 \mathrm{~mm}$ 
(17), and Riascos et al. (12) reported AP diameter as $4.6 \mathrm{~mm}$. For CE blockage, generally 22 gauge $(0.643 \mathrm{~mm}$ diameter) needles are used. If the AP diameter of hiatus is below $2 \mathrm{~mm}$, it may cause difficulties and failure in CE blockage (16). In the current study, the AP diameter of the hiatus was below $2 \mathrm{~mm}$ in $5 \%$ of the participants. While the AP diameter of the hiatus was below $2 \mathrm{~mm}$ in $6.25 \%$ of cases in the study by Senoglu et al., (17), it was below $2 \mathrm{~mm}$ in $7 \%$ of cases in the study by Riascos et al. (12). In the present study, it was observed that AP diameters of sacral hiatus and sacral canal were smaller in the advanced age group compared to the younger age group. The sacral hiatus is covered by fibrous tissue. The sacral canal contains "sacral nerve roots, filum terminale external and fibro fatty tissue" (20). The cause of the change in diameter may be due to changes in the tissue structure due to aging.

Applications of minimally invasive diagnostic and therapeutic procedures are increasingly widespread with the approach similar to CEB. Dimensions of equipment such as fiberscopes are defined according to anatomical limitations in this area. Moreover, manipulations of expensive and easily damaged materials are applied according to anatomical structure of this area. Currently there are many fiberscopes with small diameters, which are used for epidural or spinal endoscopy. One of them is Myelotec $^{\circledR}$ (Roswell, GA, USA), which is used for epidural endoscopy, and is a flexible fiber optic endoscope with an outer diameter of $0.9 \mathrm{~mm}$ (15). According to the shortest AP diameter of the sacral hiatus and sacral canal, Myelotec $^{\circledast}$ flexible fiber optic endoscope can be used in $99.7 \%$ of cases without hiatus agenesis. Outer diameters of Epi-C epiduroscope (Equip Medikey BV, Netherlands), Myelotec $^{\circledast}$ Video Guided Catheter (Myelotec, USA) and Storz Epiduroscope (Karl Storz, Tuttlingen, Germany), used for treatment and medication application in lower spine disorders, are $2.65 \mathrm{~mm}, 2.7 \mathrm{~mm}$ and $2.8 \mathrm{~mm}$ respectively $(15,14)$. These equipment can be easily used in approximately $85 \%$ of the cases. The outer diameters of the Olympus AF-5 (with rigid tip), used for spinal endoscopy, is $0.5 \mathrm{~mm}$ (18) it can be used in all of the patients without hiatus agenesis. The Olympus AF-22 (with a directable tip and one working channel) has an outer diameter of $2.2 \mathrm{~mm}$ (21), and it can be used in $93 \%$ of our cases.

The rate of hiatus agenesis was reported as $4 \%$ by Sekiguchi et al. (16); 7\% by Waldman (21); but Aggarwal et al. reported no absent hiatus (1). Hiatus agenesis was identified in $0.3 \%$ of the current cases.

An important difference between male and female patients was the sacral canal length that is associated with differences in height (9). The other important difference was observed in lordotic angle values. The curvature in females was approximately $4.5^{\circ}$ greater when compared with males. However, the difference was not so significant that it affected the equipment use between females and males.

The most remarkable angle when advancing to the lumbar area through the sacrum is the lumbosacral lordotic angle (median value of $134^{\circ}$ ). This angulation does not cause stress on the equipment. The sacral kyphotic curvature was also a wide angle with a median of $164^{\circ}$, and it is not a limiting factor for equipment manipulation. The maximum curvature level is one of the important parameters affecting angle of the needle entrance (1). In the current study, the maximum curvature of the sacrum was most commonly observed at the S3 level in $62.8 \%$ of cases; at the S2 level in $27.2 \%$ of cases; and at the $\$ 4$ level in $10 \%$ of cases. The case with hiatus agenesis was male; no hiatus agenesis was observed among females.

While complete agenesis, namely the absence of the posterior wall of the sacrum, was identified in $1 \%$ of the cases, partial agenesis was identified in $1.6 \%$ of the cases. Complete agenesis was reported as $1.0 \%, 1.5 \%$, and $3.5 \%$ by Sekiguchi et al. (16), Nagar (11), and Aggarwal et al. (1), respectively. It was reported that the surrounding tissues infiltrated the anesthetic solution during caudal epidural blockage in cases with complete agenesis. Therefore, the success rate decreased (2).

In the present study, bony septum was located in the middle of the sacral canal in $2.6 \%$ of the cases. Sekiguchi et al. reported that bony septum was located in $2 \%$ of their cases (16). The presence of bony septum complicates the process of locating the opening of the sacral canal, and the insertion of instruments into the sacral canal or their movement within the canal, and may lead to the failure of the procedure.

Sacral cornu is the most important landmark used to define $\mathrm{SH}$. Because it is covered by subcutaneous adipose tissue, it can only be palpated if it has a suitable size. In the present study, bilateral absent cornu was identified as 3\%, and bilateral short cornu was identified as 7\%. Aggarwal et al. reported that they identified bilateral short cornua as $21.05 \%$ in their study (1). However, Aggarwal et al. used dry human bones, the ages of which were unknown. According to the results of the current study, cornu cannot be used as a mark in $7 \%$ of the current study's population.

The intercornual distance was reported at different values in different studies: 2.2-18.4 mm by Sekiguchi et al. (16) and 6-23.3 $\mathrm{mm}$ by Aggarwal et al. (1). The measurements from the current cases $(7-19 \mathrm{~mm})$ were between the previously reported measurements. The length of $\mathrm{SH}$ showed a wide range of variability in different studies. It was reported as 5-38.6 $\mathrm{mm}$ by Aggarwal et al. (1) and 4.3-69 $\mathrm{mm}$ by Nagar et al. (11). The measurements from the current cases (4.5-42 $\mathrm{mm}$ ) were between the values reported in previous studies. Although long hiatus enables entrance to the sacral canal, it also increases probability of dural sac puncture by the needle.

One of the most important findings of this study was the definition of the shortest distance and its location of the AP diameter at the midline of the sacral canal. Information about the measurement and location of the shortest AP diameter were not encountered in the literature. The sacral canal narrowed at a specific area in approximately $60 \%$ of cases. The mean of the shortest AP diameter of the canal was shorter than the AP diameter of the hiatus in those cases. Cadaver 
studies should be conducted as the next step to investigate the cause and detailed examination of this narrowing.

In the present study, evaluating the morphometric analysis of sacral structures, bony anatomic abnormalities such as absent hiatus $(0.3 \%)$, complete agenesis $(1 \%)$, and bony septum (2.6\%) were identified. Those anatomic abnormalities may cause failures of interventional procedures. Anatomic differences due to gender seem to be clinically insignificant. The AP diameter and area of the sacral hiatus and the AP diameter of the sacral canal decrease with the advanced age. Fiberoptic equipment with less than $1 \mathrm{~mm}$ in diameter is required for only $0.3 \%$ of the population. Cadaver studies are required for detailed investigations of AP diameter narrowing at the midline of the sacral canal. Variability of reported values from different studies may be caused by differences between live and postmortem tissues or racial diversity. During interventional procedures through the sacral canal, the anatomical structure of the area and variations should be considered.

\section{REFERENCES}

1. Aggarwal A, Aggarwal A, Harjeet, Sahni D: Morphometry of sacral hiatus and its clinical relevance in caudal epidural block. Surg Radiol Anat 31: 793-800, 2009

2. Black MG: Anatomic reasons for caudal anesthesia failure. Anesth. Analg (Cleve) 28:33-39,1949

3. Bosscher HA, Heavner JE: Diagnosis of the vertebral level from which low back or leg pain originates. A comparison of clinical evaluation, MRI and epiduroscopy. Pain Pract 12:506512, 2012

4. Buckwalter KA, Rydberg J, Kopecky KK, Crow K, Yang EL: Musculoskeletal imaging with multislice CT. AJR Am J Roentgenol 176:979-986,2001

5. Bush K, Hillier S: A controlled study of caudal epidural injections of triamcinolone plus procaine for the management of intractable sciatica. Spine 16:572-575,1991

6. Chen PC, Tang SFT, Hsu TC et al: Ultrasound guidance in caudal epidural needle placement. Anaesthesiology 101:181184,2004

7. Cuckler JM, Bernini PA, Wiesel SW: The use of epidural steroids in the treatment of radicular pain. J Bone Joint Surg Am 67: 63-66, 1985
8. Faul F, Erdfelder E, Lang A, Buchner A: G Power 3: A flexible statistical power analysis for the social, behavioral, and biomedical sciences. Behavior Research Methods 39:175-191, 2007

9. Karakas HM, Celbis O, Harma A, Alicioglu B: Total body height estimation using sacrum height in Anatolian Caucasians: Multidetector computed tomography-based virtual anthropometry. Skeletal Radiol 40: 623-630, 2011

10. Mathews MS, Ospina J, Suzuki S: The sacral hiatus approach for drainage of anterior lumbo-sacral epidural abscesses: A case report and technical note. Interventional Neuroradiology 17: 482, 2011

11. Nagar SK: A study of sacral hiatus in dry human sacra. J Anat Soc India 53:18-21, 2004

12. Riascos, R, Vu L, Cuellar H, Haberman A, Nishino T, Layer, L: CT evaluation of caudal versus lumbar access to the intradural space. Neurological Research 33:1094-1098, 2011

13. Richter EO, Abramova MV, Cantu F, DeAndres J, Lierz P, Manchiaro P, Alo KM: Anterior epiduroscopic neural decompression: Eight center experience in 154 patients. European Journal of Pain Supplements 5(S2):401-407, 2011

14. Saberski LR: The history of epiduroscopy (spinal canal endoscopy). The Pain Clinic 9:141-148, 2007

15. Schütze G: Epiduroscopic equipment and surgical setting. Epiduroscopy, Spinal Endoscopy. Heidelberg: Springer, 2008:47-66

16. Sekiguchi M, Yabuki S, Satoh K, Kikuchi S: An anatomic study of the sacral hiatus: A basis for successful caudal epidural block. Clin J Pain 20:51-54, 2004

17. Senoglu N, Senoglu M, Oksuz H et al: Landmarks of the Sacral hiatus for caudal epidural block: An anatomical study. $\mathrm{Br} \mathrm{J}$ Anaesth 95:692-695, 2005

18. Shimada S, Tamaki N: Assessment of safety and feasibility of spinal endoscope in the thoracic and lumbar region: $A$ cadaveric study. Kobe J Med Sci 47: 263-272, 2001

19. Solomon LB, Rühli FJ, Lee YC, Henneberg M: Secular trend in the opening of the sacral canal: an Australian study. Spine 34: 244-248, 2009

20. Veering B: Regional anaesthesia in the elderly. Principles and Practice of Regional Anaesthesia. Oxford University Pres, 2012:263.

21. Waldman SD: Caudal epidural nerve block: Prone position. In: Atlas of Interventional Pain Management. Philadelphia: Saunders, 2004:380-392 